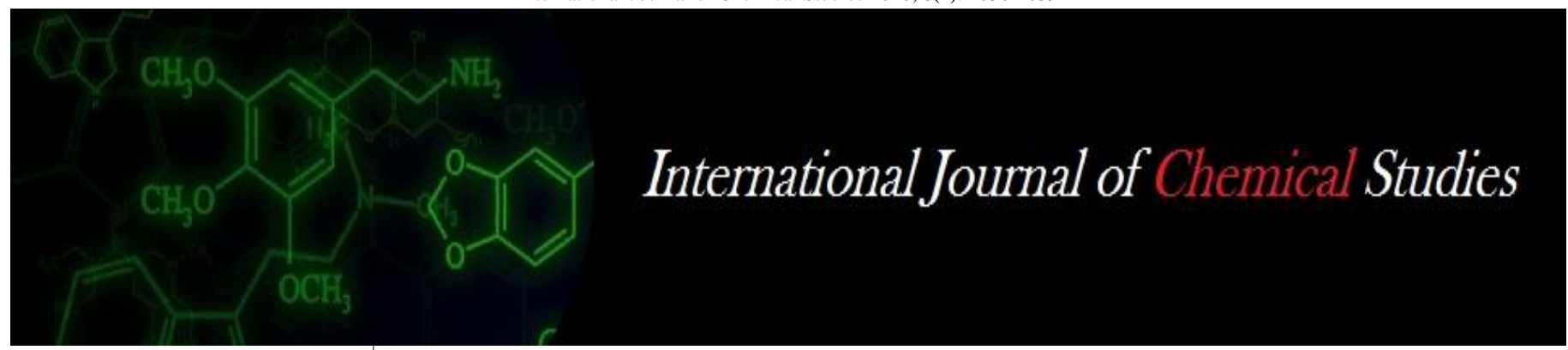

P-ISSN: 2349-8528

E-ISSN: 2321-4902

www.chemijournal.com

IJCS 2020; 8(4): 1036-1039

(C) 2020 IJCS

Received: 27-05-2020

Accepted: 29-06-2020

Somagaini Pavankumar

Division of Sericulture,

Agricultural Sciences and

Technology of Jammu, Chatha,

India

Kamlesh Bali

Division of Sericulture,

Agricultural Sciences and

Technology of Jammu, Chatha,

India

Suraksha Chanotra

P.G. Deptt. of Sericulture,

Poonch Campus, University of

Jammu, Jammu \& Kashmir,

India
Corresponding Author: Somagaini Pavankumar Division of Sericulture, Agricultural Sciences and Technology of Jammu, Chatha, India

\section{Impact of organic based nutrient management on growth and yield parameters of mulberry (Morus sp.)}

\author{
Somagaini Pavankumar, Kamlesh Bali and Suraksha Chanotra
}

DOI: https://doi.org/10.22271/chemi.2020.v8.i4h.9738

\begin{abstract}
The experiment was conducted to know the effect of different organic manures alone and in combination with biofertilizer (Azospirillum) on growth and yield parameters of mulberry (Var. China white). The experiment revealed significant differences with respect to treatments. Among these, application of Vermicompost @ 4kg/plant + Azospirillum (4.0g/plant) was recorded significantly higher growth parameters (plant girth, plant height, number of shoots per plant, shoot height, longest shoot, internodal length) and yield parameters (number of leaves per plant, fresh leaf yield, leaf area index, moisture content (\%), moisture retention per cent after 6 hours). Further FYM@4kg/plant + Azospirillum (4.0g/plant) found next best with respect to economic traits of mulberry. The results of the present study showed superiority of application of Vermicompost @ 4kg/plant + Azospirillum (4.0g/plant) after pruning so as to produce good quality mulberry leaves which in turn may improve soil health.
\end{abstract}

Keywords: Mulberry, organic manures, bio-fertilizer, growth, yield

\section{Introduction}

The sustainability of sericulture largely depends on the production of quality mulberry foliage, this is because, leaf quality influences not only the growth and development of silkworm but also the quality and quantity of silk produced (Krishnaswami, 1986) ${ }^{[5]}$. Mulberry leaf is the sole Source of food for silkworm (Bombyx mori L.) providing more than 70 per cent of the material to biosynthesize silk proteins, sericin and fibroin. However, the highly intensive mulberry cropping system results in depletion of nutrients in soil, and excess application of inorganic fertilizers and pesticides causes deleterious effect on soil health. Furthermore, it has been observed that soil chemical properties and micro-flora associated with mulberry are adversely affected with the indiscriminate application of chemical fertilizers (Siddaramappa, 2004). In this context, it is highly imperative to supply major nutrients to mulberry through organic manures and biofertilizers. Organic manures are bulky in nature which encourages the proliferation of soil microflora and supplement the crop with small amounts of major nutrients like NPK and other minor nutrients required by the crop (Lakshmi et al.,1977) ${ }^{[6]}$. Introduction of crop benefiting microbial inoculants into soil plays a significant role in the mobilization of various nutrients needed by the crop. Application of different organic manures and biofertilizers along with lower dose of fertilizers plays a significant role in enhancing the soil fertility in terms of macronutrients, secondary nutrients and microbial population (Shashidhar et al., 2018) ${ }^{[12]}$. Since mulberry is a non leguminous crop, as such free living and associative nitrogen fixing microorganisms play an important role in improving growth and yield. Application of microbial inoculants in conjunction with organic manures has significantly increased the productivity of mulberry leaf (Rashmi et al., 2009). With this background the present study was undertaken to estimate the impact of application of FYM, vermicompost, silkworm rearing waste, neem cake alone and in combination with Azospirillum on the production of quality mulberry foliage which in turn may exhibit significant bearing on growth and yield parameters of mulberry. 


\section{Materials and Methods}

The present investigation was carried out at the Experimental farm of the Division of Sericulture, Sher-e-Kashmir University of Agricultural Sciences and Technology of Jammu, Chatha, during 2018-19. The Experimental Farm of the Division of Sericulture is located at an altitude of about $332 \mathrm{~m}$ above mean sea level, lying between $32^{\circ} 39^{\prime} \mathrm{N}$ latitude and $74^{\circ} 47^{\prime}$ E longitude. Agro climatically the location represents Zone V of Jammu and Kashmir, characterized by subtropical climate. The Jammu plains and low hills including experimental location normally experience hot dry summer, hot and humid rainy season and cold winter months. The maximum temperature goes up to $45^{\circ} \mathrm{C}$ during summers (May to June) and minimum temperature falls to $4^{\circ} \mathrm{C}$ during winters and fluctuates between $14-18^{0} \mathrm{C}$. The mean annual rainfall is about 1000-1200 $\mathrm{mm}$. The soil structure of the experimental farm is sandy clay loam with $\mathrm{pH}$ 7.12. The soil fertility of the experimental site was brought to homogeneous condition without applying any organic manures or fertilizers before raising mulberry crop for the present experiment. Experiment was carried out by applying organic manures alone and in combination with biofertilizer. No inorganic fertilizer was applied to soil before raising mulberry crop for the present experiment. To know the effect of different organic manures on growth, yield and quality of mulberry (var. China white, 2 years old plantation) the following treatment combinations were used.
$\mathrm{T}_{1} \quad:$ FYM @ $4 \mathrm{~kg} /$ plant
$\mathrm{T}_{2} \quad$ : Vermicompost @ 4kg /plant
$\mathrm{T}_{3} \quad$ : Silkworm Rearing Waste @ 3kg /plant
$\mathrm{T}_{4} \quad:$ Neem cake @ 2.5kg/plant
$\mathrm{T}_{5} \quad$ :FYM @ 4kg /plant + Azospirillum (4.0g/plant)
T6 : Vermicompost @ 4kg /plant + Azospirillum (4.0g/plant)
$\mathrm{T}_{7} \quad$ : Silkworm Rearing Waste @ 3kg /plant + Azospirillum (4.0g/plant)
$\mathrm{T}_{8} \quad$ : Neem cake @ 2.5kg/plant + Azospirillum (4.0 g /plant)
$\mathrm{T}_{9} \quad$ : Control (No manure/fertilizer application)

The treatments were applied in randomized block design (RBD) with three replications after pruning of mulberry plants in the last week of December, 2018. All cultural practices were carried out as per the package of practices for mulberry garden under pit system of cultivation (Dandin et al., 2010).

\section{Statistical Analysis}

All the data recorded during the course of experimentation was analyzed by using statistical package (SPSS 16.0). Effects of different treatments on growth and yield parameters of mulberry were analyzed using one way ANOVA. Differences between means were tested by using Tukey's HSD $(\mathrm{P}<0.05)$

\section{Results and Discussion}

The results of the present study are tabulated in tables 1 to 2 and are interpreted in the light of earlier work are here under.

\section{Growth parameters of mulberry}

The data presented in the table 1 reveals that application of different organic manures alone and in combination with Azospirillum showed significant impact on plant girth $(\mathrm{cm})(\mathrm{F}$ $=144.715 ; \mathrm{df}=8 ; \mathrm{p}=0.000)$, maximum being with the application of vermicompost + Azospirillum (7.50 \pm 0.13 ) followed by FYM + Azospirillum $\left(\mathrm{T}_{5}\right)(7.20 \pm 0.06)$ and $\mathrm{T}_{8}$ $(6.90 \pm 0.01)$ respectively over other treatments. While the lowest result was recorded in control $\left(\mathrm{T}_{9}\right)(5.10 \pm 0.06)$ which was at par with $\mathrm{T}_{3}(5.06 \pm 0.07)$. Application of vermicompost + Azospirillum exhibited better result for plant height $(\mathrm{F}=4.887 ; \mathrm{df}=8 ; \mathrm{p}=0.002),(284.67 \pm 7.36)$ which was at par with $\mathrm{T}_{5}(279.33 \pm 5.53)$ and $\mathrm{T}_{8}(275.50 \pm 10.15)$ whereas it was significantly less in Control $\left(\mathrm{T}_{9}\right)(227.50 \pm$ 7.50). Shoot height $(\mathrm{F}=3.491$; $\mathrm{df}=8 ; \mathrm{p}=0.013)$, in respect of this parameter application of vermicompost + Azospirillum ( $\left.\mathrm{T}_{6}\right)$ exhibited better results $(146.63 \pm 8.03)$ which was at par with $\mathrm{T}_{5}(143.90 \pm 7.43)$ whereas it was significantly less in Control $\left(\mathrm{T}_{9}\right)(90.50 \pm 11.02)$. However, non significant differences were observed between $\mathrm{T}_{8}(135.23 \pm 8.77), \mathrm{T}_{2}$ $(132.93 \pm 3.84), \mathrm{T}_{7}(127.60 \pm 6.34), \mathrm{T}_{1}(121.93 \pm 10.53), \mathrm{T}_{4}$ $(117.00 \pm 13.82)$ and $\mathrm{T}_{3}(116.57 \pm 8.71)$. Longest shoot $(\mathrm{F}=$ 3.477 ; df $=8 ; \mathrm{p}=0.013)$, in respect of this parameter application of vermicompost + Azospirillum ( $\mathrm{T}_{6}$ ) exhibited better results $(158.27 \pm 6.71)$ which was at par with $\mathrm{T}_{5}$ $(157.37 \pm 4.64)$ and $\mathrm{T}_{8}(155.93 \pm 10.40)$ whereas it was significantly less in Control $\left(\mathrm{T}_{9}\right)(114.67 \pm 5.83)$. However, no significant difference was found in number of shoots per plant and internodal length in mulberry.

This is due to the fact that combined application of organic manures and bio-fertilizers not only helps in sustaining the soil fertility but also improve the mulberry productivity, nutrient use efficiency, biodiversity and soil environment (Senapati et al., 2005 and Moradi et al., 2014) ${ }^{[11,8]}$. These results are in close conformity with the results obtained by Naika et al. (2012) [9]; Singh et al. (2012) [15]; Dhanalakshmi et al. (2014) [3]; Moradi et al. (2014) [8]; Umesha and Sannappa (2014). The results of Baqual and Das (2006) in improving mulberry leaf quality and quantity by application of Azospirilum confirms the present finding and economic potentiality of using Azospirilum in combination with FYM in mulberry cultivation. The findings of the present investigations are more in conformity with the above research workers.

\section{Yield parameters of mulberry}

The data presented in the table 2 reveals that application of different organic manures alone and in combination with biofertilizer (Azospirillum) to mulberry tree exhibited significant result in respect of number of leaves per plant $(\mathrm{F}=$ $2.825 ;$ df $=8 ; \mathrm{p}=0.032$ ), maximum being with the application of vermicompost + Azospirillum $\left(\mathrm{T}_{6}\right)(1203.33 \pm$ $60.92)$ followed by $\mathrm{T}_{5}(1164.67 \pm 102.53)$ which was found statistically at par with $\mathrm{T}_{8}(1108.33 \pm 62.69)$ whereas it was significantly less in control $\left(\mathrm{T}_{9}\right)(742.00 \pm 40.22)$. Fresh leaf yield $(\mathrm{F}=32.694 ; \mathrm{df}=8 ; \mathrm{p}=0.000)$, in respect of this parameter application of vermicompost + Azospirillum $\left(\mathrm{T}_{6}\right)$ exhibited better results $(3013.00 \pm 71.00)$ which was at par with $\mathrm{T}_{5}(2991.00 \pm 67.10)$ whereas it was significantly less in Control $\left(\mathrm{T}_{9}\right)(1997.00 \pm 38.74)$. However, non significant differences were observed between $\mathrm{T}_{2}(2672.00 \pm 62.02)$ and $\mathrm{T}_{7}(2645 \pm 54.90)$. Leaf area index $(\mathrm{F}=7.386 ; \mathrm{df}=8 ; \mathrm{p}=$ $0.000)$, in respect of this parameter application of vermicompost + Azospirillum $\left(\mathrm{T}_{6}\right)$ exhibited better results $(1.54 \pm 0.02)$ which was at par with $\mathrm{T}_{5}(1.51 \pm 0.01)$ and $\mathrm{T}_{8}$ $(1.50 \pm 0.01)$ whereas it was significantly less in Control $\left(\mathrm{T}_{9}\right)$ $(1.31 \pm 0.06)$. Moisture content of leaf $(\mathrm{F}=3.073 ; \mathrm{df}=8 ; \mathrm{p}=$ 0.023 ) in respect of this parameter application of vermicompost + Azospirillum $\left(\mathrm{T}_{6}\right)$ exhibited better results $(72.02 \pm 1.05)$ which was at par with $\mathrm{T}_{5}(69.80 \pm 1.16)$ whereas it was significantly less in Control $\left(\mathrm{T}_{9}\right)(61.82 \pm$ 1.17) which was at par with $T_{4}(66.71 \pm 2.58)$ and $T_{3}(66.36 \pm$ 2.03). However, non significant differences were observed between $\mathrm{T}_{8}(68.36 \pm 0.93), \mathrm{T}_{2}(67.57 \pm 0.28), \mathrm{T}_{7}(67.40 \pm$ 
1.46) and $T_{1}(67.00 \pm 1.75)$. Moisture retention of leaf after 6 hours $(\mathrm{F}=70063.530 ; \mathrm{df}=8 ; \mathrm{p}=0.000)$. In respect of this parameter application of vermicompost + Azospirillum $\left(\mathrm{T}_{6}\right)$ exhibited better results $(74.43 \pm 0.01)$ followed by $\mathrm{T}_{5}(72.17 \pm$ $0.02)$ and $\mathrm{T}_{8}(70.30 \pm 0.01)$ respectively over other treatments whereas it was significantly less in Control ( $\left.\mathrm{T}_{9}\right)$ (63.42 \pm 0.02 ).

These results are in conformity with the findings of Sudhakara et al. (2017) in which they used vermicompost with 50 per cent of NPK and Azospirilum with 25 per cent of compost, green manure, castor oil cake and vermicompost. But there is slight variation in the results as obtained by Suvarna (2007) ${ }^{[7]}$, revealed that highest number of leaves per plant in case of Azospirilum application and lowest in case of neem cake and vermicompost application in brinjal crop. The difference between the results can be attributed to the selection of different crops and dosage of manures applied under different agro-climatic conditions. Jayathilake et al. (2006) reported similar results in which Azospirilum in combination with FYM and Azotobacter in combination with FYM and chemical fertilizer was used and recorded 14.79 and 13.36 per cent more yield than control respectively and revealed its beneficial effect as earlier described by Shinde et al. (1992) ${ }^{[13]}$; Naika et al. (2012) ${ }^{[9]}$; Umesha and Sannappa (2014) ${ }^{[18]}$ and Mallappa et al. (2016) ${ }^{[7]}$.

Table 1: Effect of organic manures alone and in combination with Azospirillum on growth parameters of mulberry (var. China white)

\begin{tabular}{|c|c|c|c|c|c|c|}
\hline Treatments & $\begin{array}{c}\text { Plant girth } \\
(\mathbf{c m})\end{array}$ & $\begin{array}{c}\text { Plant height } \\
(\mathbf{c m})\end{array}$ & $\begin{array}{c}\text { Number of shoots } \\
\text { per plant }\end{array}$ & $\begin{array}{c}\text { Shoot height } \\
(\mathbf{c m})\end{array}$ & $\begin{array}{c}\text { Longest shoot } \\
(\mathbf{c m})\end{array}$ & $\begin{array}{c}\text { Internodal length } \\
(\mathbf{c m})\end{array}$ \\
\hline $\mathrm{T}_{1}$ & $6.10 \pm 0.06 \mathrm{bc}$ & $258.00 \pm 8.89 \mathrm{ab}$ & $12.67 \pm 1.20 \mathrm{a}$ & $121.93 \pm 10.53 \mathrm{ab}$ & $141.17 \pm 7.30 \mathrm{ab}$ & $5.27 \pm 0.19 \mathrm{a}$ \\
\hline $\mathrm{T}_{2}$ & $6.40 \pm 0.01 \mathrm{c}$ & $265.17 \pm 4.57 \mathrm{ab}$ & $14.33 \pm 1.20 \mathrm{a}$ & $132.93 \pm 3.84 \mathrm{ab}$ & $149.43 \pm 6.50 \mathrm{ab}$ & $5.20 \pm 0.21 \mathrm{a}$ \\
\hline $\mathrm{T} 3$ & $5.06 \pm 0.07 \mathrm{a}$ & $251.33 \pm 5.93 \mathrm{ab}$ & $12.00 \pm 0.58 \mathrm{a}$ & $116.57 \pm 8.71 \mathrm{ab}$ & $124.10 \pm 14.34 \mathrm{ab}$ & $5.40 \pm 0.06 \mathrm{a}$ \\
\hline $\mathrm{T} 4$ & $5.80 \pm 0.10 \mathrm{~b}$ & $253.83 \pm 10.46 \mathrm{ab}$ & $12.00 \pm 0.58 \mathrm{a}$ & $117.00 \pm 13.82 \mathrm{ab}$ & $139.60 \pm 7.66 \mathrm{ab}$ & $5.37 \pm 0.15 \mathrm{a}$ \\
\hline $\mathrm{T} 5$ & $7.20 \pm 0.06 \mathrm{de}$ & $279.33 \pm 5.53 \mathrm{~b}$ & $15.00 \pm 1.00 \mathrm{a}$ & $143.90 \pm 7.43 \mathrm{~b}$ & $157.37 \pm 4.64 \mathrm{~b}$ & $5.07 \pm 0.09 \mathrm{a}$ \\
\hline $\mathrm{T} 6$ & $7.50 \pm 0.13 \mathrm{e}$ & $284.67 \pm 7.36 \mathrm{~b}$ & $15.33 \pm 1.20 \mathrm{a}$ & $146.63 \pm 8.03 \mathrm{~b}$ & $158.27 \pm 6.71 \mathrm{~b}$ & $5.00 \pm 0.40 \mathrm{a}$ \\
\hline $\mathrm{T} 7$ & $6.30 \pm 0.05 \mathrm{c}$ & $264.17 \pm 7.97 \mathrm{ab}$ & $13.67 \pm 1.45 \mathrm{a}$ & $127.60 \pm 6.34 \mathrm{ab}$ & $142.57 \pm 4.58 \mathrm{ab}$ & $5.23 \pm 0.18 \mathrm{a}$ \\
\hline $\mathrm{T} 8$ & $6.90 \pm 0.01 \mathrm{~d}$ & $275.50 \pm 10.15 \mathrm{~b}$ & $14.67 \pm 1.86 \mathrm{a}$ & $135.23 \pm 8.77 \mathrm{ab}$ & $155.93 \pm 10.40 \mathrm{~b}$ & $5.17 \pm 0.23 \mathrm{a}$ \\
\hline $\mathrm{T} 9$ & $5.10 \pm 0.06 \mathrm{a}$ & $227.50 \pm 7.50 \mathrm{a}$ & $11.00 \pm 1.15 \mathrm{a}$ & $90.50 \pm 11.02 \mathrm{~b}$ & $114.67 \pm 5.83 \mathrm{a}$ & $5.43 \pm 0.18 \mathrm{a}$ \\
\hline
\end{tabular}

Values are Means \pm SE

Means within a column followed by different letters are significantly different $\mathrm{P}<0.05$

Table 2: Effect of organic manures alone and in combination with Azospirillum on yield parameters of mulberry (var. China white)

\begin{tabular}{|c|c|c|c|c|c|}
\hline Treatments & $\begin{array}{c}\text { Number of leaves } \\
\text { per plant }\end{array}$ & $\begin{array}{c}\text { Fresh leaf yield } \\
\text { (g/plant) }\end{array}$ & $\begin{array}{c}\text { Leaf area index } \\
(\mathbf{L A I})\end{array}$ & $\begin{array}{c}\text { Moisture content } \\
(\%)\end{array}$ & $\begin{array}{c}\text { Moisture retention }(\%) \\
\text { after 6 hours }\end{array}$ \\
\hline $\mathrm{T} 1$ & $992.67 \pm 1.35 \mathrm{ab}$ & $2585.00 \pm 50.93 \mathrm{bc}$ & $1.47 \pm 0.02 \mathrm{~b}$ & $67.00 \pm 1.75 \mathrm{ab}$ & $68.76 \pm 0.01 \mathrm{~d}$ \\
\hline $\mathrm{T} 2$ & $1056.67 \pm 91.60 \mathrm{ab}$ & $2672.00 \pm 62.02 \mathrm{c}$ & $1.49 \pm 0.01 \mathrm{~b}$ & $67.57 \pm 0.28 \mathrm{ab}$ & $69.41 \pm 0.01 \mathrm{f}$ \\
\hline $\mathrm{T} 3$ & $864.33 \pm 73.27 \mathrm{ab}$ & $2317.00 \pm 47.13 \mathrm{~b}$ & $1.44 \pm 0.01 \mathrm{~b}$ & $66.36 \pm 2.03 \mathrm{a}$ & $68.06 \pm 0.01 \mathrm{~b}$ \\
\hline $\mathrm{T} 4$ & $988.00 \pm 75.62 \mathrm{ab}$ & $2571.00 \pm 57.12 \mathrm{bc}$ & $1.46 \pm 0.01 \mathrm{~b}$ & $66.71 \pm 2.58 \mathrm{a}$ & $68.45 \pm 0.01 \mathrm{c}$ \\
\hline $\mathrm{T} 5$ & $1164.67 \pm 102.53 \mathrm{ab}$ & $2991.00 \pm 67.10 \mathrm{~d}$ & $1.51 \pm 0.01 \mathrm{~b}$ & $69.80 \pm 1.16 \mathrm{~b}$ & $72.17 \pm 0.02 \mathrm{~h}$ \\
\hline $\mathrm{T} 6$ & $1203.33 \pm 60.92 \mathrm{~b}$ & $3013.00 \pm 71.00 \mathrm{~d}$ & $1.54 \pm 0.02 \mathrm{~b}$ & $72.02 \pm 1.05 \mathrm{~b}$ & $74.43 \pm 0.01 \mathrm{i}$ \\
\hline $\mathrm{T} 7$ & $1050.67 \pm 96.72 \mathrm{ab}$ & $2645.00 \pm 54.90 \mathrm{c}$ & $1.48 \pm 0.01 \mathrm{~b}$ & $67.40 \pm 1.46 \mathrm{ab}$ & $69.19 \pm 0.01 \mathrm{e}$ \\
\hline T8 & $1108.33 \pm 62.69 \mathrm{ab}$ & $2842.00 \pm 50.06 \mathrm{~cd}$ & $1.50 \pm 0.01 \mathrm{~b}$ & $68.36 \pm 0.93 \mathrm{ab}$ & $70.30 \pm 0.01 \mathrm{~g}$ \\
\hline $\mathrm{T} 9$ & $742.00 \pm 40.22 \mathrm{a}$ & $1997.00 \pm 38.74 \mathrm{a}$ & $1.31 \pm 0.06 \mathrm{a}$ & $61.82 \pm 1.17 \mathrm{a}$ & $63.42 \pm 0.02 \mathrm{a}$ \\
\hline
\end{tabular}

Values are Means \pm SE

Means within a column followed by different letters are significantly different $\mathrm{P}<0.05$

\section{Conclusion}

On the basis of current findings it may been concluded that, the application of vermicompost @ $4 \mathrm{Kg}$ /plant + Azospirillum (4.0 g/plant) after pruning would be an advisable treatment so as to produce good quality mulberry leaves which in turn may improve soil health and cocoon crop as well with improved metric traits. This could be due to considerable research evidence that earthworms stimulate the microbial decomposition of organic matter significantly, thereby releasing the nutrients in available form to mulberry tree which has a direct effect on quality of mulberry leaves, which might have enhanced palatability and acceptability of leaves, increased feeding efficiency of silkworms and thereby resulting in good cocoon yield. Whereas, other organic manures like FYM, silkworm rearing waste and neem cake may require some more time to breakdown into simpler molecules and to release nutrients to the soil and making them available to mulberry tree for its utilization. Thus, application of vermicompost + Azospirillum $\left(\mathrm{T}_{6}\right)$ could form a suitable organic manure and biofertilizer combination for mulberry cultivation from overall sericultural point of view.

\section{References}

1. Baqual MF, Das PK. Influence of bio-fertilizers on macronutrient uptake by the mulberry plant and its impact on silkworm bioassay. Caspian Journal of Environmental Sciences, 2006; 4(2):98-109.

2. Dandin SB, Jayaswal J, Giridhar K. Handbook of Sericulture Technologies. Central Silk Board, Banglore, India. 2010, 25.

3. Dhanalakshmi V, Remia KM, Shanmugapriyan R, Shanthi K. Impact of addition of Vermicompost on Vegetable Plant Growth. International Research Journal of Biological Sciences, 2014; 3(12):56-61.

4. Jayathilake PKS, Reddy IP, Srihari D, Reddy KR. Productivity and soil fertility status as influenced by integrated use of n-fixing biofertilizers, organic manures and inorganic fertilizers in onion. The Journal of Agricultural Sciences, 2006; 2(1):41-48.

5. Krishnaswami, S. New Technology of Silkworm Rearing. Bulletin No. 2. Central Sericultural Research and Training Institute, Mysore, 1986, 23.

6. Lakshmi V, Sathyanarayanarao A, Vijaya Lakshmi M, Lakshmikumari M, Tilak KVBR, Subba Rao NS. 
Establishment and survival of spirillum lipoferum. In: Proceedings of Indian Academy of Science, 1977; 86(8):397-404.

7. Mallappa B, Narayana VS, Siddappa, Biradar S. Effect of Integrated nutrient management on growth and yield of mulberry (Morus alba L.). The Bioscan, 2016; 11(2):1303-1305.

8. Moradi H, Fahramand M, Sobhkhizi A, Adibian M, Noori M, Abdollahi S et al. Effect of vermicompost on plant growth and its relationship with soil properties. International Journal of Farming and Allied Sciences, 2014; 3(3):333-338.

9. Naika R, Sannappa B, Devaiah MC. Economic evaluation of organics on mulberry and cocoon production - a study. International Journal of Advanced Biological Research, 2012; 2(2):215-219.

10. Rashmi K, Shankar MA, Shashidhar KR, Narayanaswamy TK. Growth and foliar constituents of mulberry (M5) cultivated under organic based nutrient management. International Journal of Industrial Entomology, 2007; 19(1):165-169.

11. Senapati HK, Pal AK, Samant PK. Effect of chemical fertilizer, organic manure, lime and biofertilizer on yield of turmeric (Curcuma longa). Indian Journal of Agricultural Sciences, 2005; 75(9):593-595.

12. Shashidhar KR, Narayanaswamy TK, Sudhakar SN, Bhaskar RN. Impact of different sources of organic nutrients on chemical composition of s-36 mulberry and soil under irrigated condition. International Journal of Current Microbiology and Applied Sciences. 2018; 7(1):2233-2238.

13. Shinde PH, Naik RL, Nazikar RB, Kadam SK, Khaire VM. Evaluation of vermicompost. IN: Proceedings of National Seminar on Organic Farming. $8^{\text {th }}$ and $9^{\text {th }}$ October, MPKV, Pune, Indai, 1992, 92-98.

14. Siddaramappa R. Soil health and nutrient management, operational methodologies and package and practices in organic farming. In: National Seminar, APOF. Bangalore, India, 2004, 13-14.

15. Singh MK, Chowdhuri RS, Naqvi AH, Ghosh MK, Bindroo BB. Studies on integrated nutrient management on leaf yield and quality of silk of mulberry (Morus alba L.) grown under rainfed situation. Journal of Crop and Weed, 2012; 8(2):80-82.

16. Sudhakara SN, Narayanaswami TK. Late age worm (Bombyx mori L.) rearing performance as influenced by feeding schedules of mulberry leaf raised through the concept of organic based nutrient management. International Journal of Current Research, 2017; 9(10):58502-58505.

17. Suvarna G. Effect of FYM, vermicompost, neem cake and biofertilizers on growth, yield and quality of brinjal (solanum melongena L.), M.Sc. (Horti.) thesis, ANGRAU, Rajendranajar, 2007, 42.

18. Umesha A, Sannappa B. Bio-chemical and mineral constituents of mulberry leaf raised through organic based nutrients in red loamy soil. International Journal of Advanced Research, 2014; 2(9):348-355 